\title{
Research on Archivists' Professional Ethics Construction
}

\author{
Hongwei Lu \\ Shandong Technology and Business University \\ Yantai, Shandong, 264005
}

\begin{abstract}
With the development and deepening of the information age, archives, as the most original carrier of information, will play a more and more important role of "information source" and "evidence source" in the development of social economy and the construction of spiritual civilization. However, there are many problems in archives management in China, which obviously can't meet the needs of the society. Two main aspects are as follows: one is that the work of archival management is generally not paid enough attention to, the other is the aging of the knowledge structure of the archivists and the lack of the le arning spirit. In order to solve these two problems, it is essential to solve the ideological problems of archivists. That is to say, the professional ethics construction of archivists must be strengthened quickly and effectively. Good professional ethics first requires practitioners to love the work and be devoted to it. Therefore, to change the phe nomenon that the work of archival management is generally ignored and to fundamentally promote its sound development, the professional ethics of archivists, first of all, should be strengthened, and every archivist should equipped with high sense of responsibility and dedication through the construction of professional ethics. Meanwhile, only with a good professional ethics, practitioners can face the difficulties encountered in the work with a positive attitude, and constantly strengthen their own learning ability. No matter what kind of work one is engaged in, he will always encounter problems that are difficult to solve or deal with in a certain amount of time, and archivists are no exception. However, the more terrible thing is the lack of spirit of study and research rather than the problems, and good professional ethics requires the practitioners to learn and recharge constantly in their work. Therefore, the construction of professional ethics is also an effective guarantee for archivists to improve their personal quality and work level. However, the actual situation is not satisfactory. At present, the professional skills and professional ethics of archivists in China are generally not high, which has become the biggest obstacle to the development of archives in our country. As a consequence, strengthening the construction of professional ethics of archivists is a problem that must be faced and urgently solved.
\end{abstract}

Keywords-archival management, professional ethics, basic strategies

\section{BACKGROUND AND RESEARCH VALUE}

\section{A. Background}

At present, there have been some positive achievements in the exploration of archivists' moral quality in academic circles, but there is no specialized research on the construction of their professional ethics and a lack of systematic study on the problems in the construction of archival professional ethics, the cause of formation as well as related countermeasures. Based on the actual situation of occupation moral construction of archivists both at home and abroad, archivists' work condition and their performance about the common occupation moral standard in the work, this paper aims to discuss the problems of occupation moral construction and provide theoretical help to overcome these problems during the process of occupation moral construction in Archival management.

\section{B. Research value}

On the one hand, this research can help scientific community to define the intension and features of archivists' occupation ethics and to provide basic theoretical support for the occupation moral research of archivists. On the other hand, it contributes to the empirical analysis of Chinese realistic condition of archivists' occupation ethics and the provision of guidance of improving archivists' moral construction. Strengthening the archivists' moral construction will help to scientifically enforce the law for the vast number of archivists and provide a strong moral guarantee for the law enforcement of the people.

\section{THE DEFINITION of ARCHIVISTS’ Professional Ethics}

Confucius once exclaimed that if the name is not right then speech will not be in order. The core topic of this study is to explore the relevant issues in the construction of archivists' professional ethics. In order to explore this problem, we must first "correct the name" of the study object. This chapter defines the professional ethics of archivists. The so-called professional ethics is closely related to the profession, with a certain professional characteristics of the code of conduct and moral norms. Therefore, it can be seen that there are different professional ethics in different occupational categories. They may have similarities, but the distinctions are also obvious. Professional ethics is a means of adjusting the relationship between individuals and others in their professional life. By stipulating the rules of various professional activities and the obligations that should be fulfilled by professionals in all fields, the orderly conduct of various professional activities and the rational coexistence between all professions and the general morality of society can be guaranteed. Therefore, professional ethics is the specific embodiment of morality in professional life. In practice, professional ethics has four main characteristics. First is the limitation of the scope of 
professional ethics. Because of the different functions, social responsibilities and obligations of various professions, different professional ethics are formed. The scope of application of any professional ethics is not universal, but specific and limited. Although professional ethics also has some common requirements, the professional ethics of a particular profession, in most cases, are only applicable to people who specialize in this profession[2].

\section{The Main Problems in the Construction of ARChIVISTS' PROFESSIONAL ETHICS IN CHINA}

\section{A. Inadequate attention and unsound foundation}

Everything can be settled down once you treat it earnestly. Attention is the beginning of earnestness. Not all problems can be solved by attaching importance to them. But if you don't take it seriously, it definitely won't work out. At present, the most important problem in the construction of archivists' professional ethics in China is that practitioners fail to attach great importance to it. In my survey, although most of the interviewees agreed that 'there is a need to strengthen professional ethics", a number of the responses were put forward mostly for "the occasion". To quote a popular linguistic point of view, not people are talking, but words are talking. It is an answer that the archivists should give in his or her position. However, some interviewees are more honest. They believe that morality itself is intangible matter, so the level of professional ethics depends solely on their inherent quality, regardless of construction or not. These interviewees first mix professional ethics with general morality, so it is impossible for them to attach importance to the construction of professional ethics [3].

\section{B. Blank legislation and no law to obey}

At present, there is only one documented law on archives management in China, that is, the Archives Law of the People's Republic of China. It stipulates the contents, requirements, basic system and procedure of archives management, as well as the duties, the measures of rewards and punishments for archivists, etc. However, there is no expression on the construction of archivists' professional ethics in it, nor is there a special law on this aspect in China.

\section{Inadequate regulation and implementation}

Another stumbling block that obstructs the construction of archivists' professional ethics in China is the lack of supervision. According to general knowledge, supervision can be divided into three types: supervision of superior department, supervision of the object of service and mutual supervision between archivists. First of all, supervision between archivists, in a sense, can only depend on self-awareness, or through some thematic evaluation activities within the department. The effect of supervision is very limited. So the real supervision still needs to rely on the competent department or the object of service. It is obvious that these two kinds of supervision are also interrelated. If the object of service, the archive user, discovers the loophole in the management of the archivists or the problem in the professional ethics, he must report the situation to the competent department in order to play a supervisory role [5].

\section{Cause Analysis of the Problems Existing in the CONSTRUCTION OF ARCHIVISTS' Professional ETHICS IN TODAY'S CHINA}

\section{A. Archivists' lack of initiative for improving their professional ethics.}

Archival work is considered to be political and confidential, which requires that practitioners should have strong political and ideological qualities. And the ideological quality also directly affects the work efficiency. If the archivists lack a correct understanding of the important significance of archival work in the construction of material and spiritual civilization in China, slack off thinking, paying little attention to the perfection of their own thoughts, have weak sense of political responsibility and work perseverance, the healthy development of archival work in China will be affected.

\section{B. Unsound laws and regulations for the construction of archivists' professional ethics}

The blank legislation is not only an important problem in the construction of archivists' professional ethics, but also the cause of archivists' low level of professional ethics. Archives bear the history of national development and the overall social spiritual sustenance. The concept, attitude and skill of archivists directly reflect their quality and accomplishment. And the level of professional ethics of archivists is directly related to their working ability and the quality of archival information. Therefore, the law and the strong supervision must be set up as the safeguard.

\section{Incomplete supervision mechanism of the construction of archivists' professional ethics}

In order to strengthen the construction of archivists' professional ethics, it is necessary to establish the corresponding supervision mechanism and form a multipronged cross-supervision system. Specifically, the first is the implementation of leadership supervision. Leaders at all levels of archival departments should list strengthening the construction of professional ethics in their work schedules, constantly improve the professional ethics standards of archivists, and carry out daily supervision. The second is to establish an evaluation mechanism. Work evaluation should be pertinently implemented according to the different periods, nature and characteristics of the archives management. Then on the basis of the evaluation results, virtue should be glorified and vice censured, and the criticism and self-criticism should be carried out, for strengthening the professional ethics consciousness of the archivists. The third is to strengthen the supervision of public opinion. Good moral demeanor should be eulogized, and the bad deeds of some practitioners in the process of archives management should be exposed and cracked down, to create a professional atmosphere that advocates justice. 


\section{THE BASIC COUNTERMEASURES FOR STRENGTHENING Professional ETHICS CONSTRUCTION OF ARCHIVISTS IN CHINA}

\section{A. To strengthen ideological and political education and consolidate the foundation for professional ethics}

Professional ethics comes down to a matter of morality. Moral problems come down to people's ideological problems because morality will eventually need implementing by people. Therefore, solving people's ideological problems is the fundamental starting point and end-result of professional ethics construction. [7] File management work is a very political job. Therefore, the professional ethics construction of archivists is first of all to resolve their ideological problems, that is, to make the thinking of archivists consistent with the dominant thoughts of our country and our party through education. [8]

\section{B. To improve professional ethics and strengthen protection of laws and regulations}

Professional ethics have both the subjectivity of morality and meanwhile it is mandatory. If various forms of professional ethics education are aimed at solving the subjective problems of practitioners, then the legal and institutional construction is to solve its "mandatory" aspects, that is, to provide a strong guarantee for the observance of professional ethics of archivists. And to moderately punish those who violates the observance of professional ethics. One the one hand, it can alert violators that violations shall not happen again. In addition, it can also function as a warning to others. The law, which is mandatorily enacted and guaranteed by the state, is a code of conduct for the maintenance of normal social relations between people. The law is inherently obligatory. What the mandatory nature of the law and the professional ethics has in common is that the purpose of the law is to safeguard the normal social relations between people, and morality and professional ethics also have the same effect, yet the scope of application of the two is different.

\section{To improve the mechanism of professional ethics education, and focus on sound personality and effectiveness}

Strengthening the professional ethics construction of archivists is not only an important part of China's socialist spiritual civilization construction but also an urgent issue that needs resolving. The management of archives is related to all aspects of social life. In the information age, this kind of connection is increasing day by day. Therefore, it is imperative to strengthen the professional ethics construction of archivists, and it is extremely necessary to provide relevant education for practitioners.

\section{To improve the restraint mechanism of professional ethics and strengthen the construction of positive propaganda mechanism}

Strengthening the professional ethics of archivists by selfconsciousness is far from enough, and it is necessary to establish relevant supervisory mechanisms. To strengthen the professional ethics of archivists through the internal and external efforts. We can start from the three aspects: internal supervision, external supervision and positive publicity.

\section{CONCLUSION}

China is an ancient country with a history of civilization of more than 2,000 years. A large number of archives passed on have not only recorded the history of China, but also carried the spiritual beliefs of the Chinese nation. The current era is an era of "information explosion". Information in various forms and through various carriers has a profound impact on people's lives. As an information carrier, archives occupy an irreplaceable position in many information carriers with its originality and authority, and its role in China's social and economic construction as well as the spiritual civilization construction will become increasingly important. As the "gatekeeper" of archives, archivists are responsible for the collection, sorting and identification of archives. The responsibilities they take on are self-evident. In particular, some archives involving confidentiality are directly related to China's national security and the fundamental interests of masses of people. The construction of professional ethics is also a powerful guarantee for archivists to improve their personal and working qualities. This paper provides theoretical support for the professional ethics construction of archivists through strengthening ideological and political education, strengthening the foundation of professional ethics, improving professional ethics, strengthening the protection of laws and regulations, improving mechanisms of professional ethics education, emphasizing personality soundness and effectiveness, strengthening the restraint mechanism of professional ethics, and strengthening the construction of positive advocacy mechanisms.

\section{REFERENCES}

[1] Qian Huanqi. An Introduction to Professional Ethics[M]. Nanjing: Nanjing Normal University Press, 2006: 47.

[2] Gao Wenhua. Thinking on the Construction of High-Quality Archive Talents[J].Shandong Archives,2011(5):19.

[3] Wang Dongdong. Professional and Moral Cultivation of Archivists[J].Heilongjiang Archives,2010(5):15.

[4] Guo Shuping. On the Construction of Archives Professional Ethics [J]. Archives professional ethics, 2009 (3): 29.

[5] Wang Ming. On the Construction of Professional Ethics of Archivists[J].Zhejiang Archives,2011(1):9.

[6] Qin Jingze. Reflections on Professional Ethics of Archivists[J]. Archives, 1998(4):13.

[7] Hu Dongmei. Archives Business Tutorial[M]. Changchun: Jilin Archives Publishing House, 2003:38.

[8] Wang Taiping. Efforts to improve the Quality of Archiv ists[J]. Journal of Shanxi Finance and Economics University, 2001 (23): 8. 